\title{
WOMEN'S \\ SUBORDINATION \\ AND THEIR \\ RIGHT \\ TO RESIST ${ }^{1}$
}

\section{LA SUBORDINACIÓN DE LAS MUIERES Y SU DERECHO DE RESISTENCIA}

\author{
A SUBORDINAÇÃO DAS MULHERES E SEU DIREITO DE RESISTIR
}

Eduarda Calado Barbosa*

Consejo Nacional de Investigaciones Científicas y Técnicas

\begin{abstract}
This essay seeks to combine Frèdéric Gros' concept of subordination, presented in Disobey: The philosophy of Resistance, with the theory of women's subordination proposed by feminist philosophers aligned with the Speech Acts Theory framework. It purports to show that the paternalism identified by Gros as a trademark of subordinative arrangements is present as such in sexist societies, playing a justificatory role in what concerns the morality of the subordination of women to men. The text discusses uses of sexist derogatory words to show that such words reflect a patriarchal worldview, evoking paternalistic stereotypes. Additionally, it is argued that counter-speech and slur appropriation can work as efficacious forms of resistance and disobedience to the patriarchy.
\end{abstract}

KEYWORDS: Women's subordination. Sexism. Insult. Counter-speech. Appropriation.

RESUMO: Este ensaio procura combinar o conceito de subordinação apresentado por Frèdéric Gros, em Desobedecer, à teoria da subordinação feminina, proposta por filósofas feministas vinculadas à Teoria dos Atos de fala. O propósito é mostrar que o paternalismo, identificado por Gros como uma marca registrada dos acordos subordinativos, está, como tal, presente em sociedades sexistas, desempenhando o papel de justificativa moral da subordinação das mulheres aos homens. O texto discute usos de insultos sexistas para mostrar como tais palavras refletem a visão de mundo patriarcal e evocam estereótipos paternalistas. Adicionalmente, argumenta-se que o contradiscurso e a reapropriação de palavras ofensivas podem funcionar como formas efetivas de resistência e desobediência ao patriarcado.

PALAVRAS-CHAVE: Subordinação feminina. Sexismo. Insulto. Contradiscurso. Reapropriação.

\footnotetext{
${ }^{1}$ The author thanks the valuable contributions given by Dra. Vanice Sargentini, Dra. Amanda Braga and Dra. Oriana Fulaneti to the development of this work.

* PhD in philosophy from the Federal University of Minas Gerais (UFMG). Currently, she is a fellow researcher at the Instituto de Investigaciones Filosóficas/Sociedad Argentina de Análisis Filosófico/CONICET (IIF/SADAF/CONICET), holding a postdoctoral scholarship from the Consejo Nacional de Investigaciones Científicas y Técnicas (CONICET). ORCID: https://orcid.org/0000-0002-2478-9670. E-mail: eduardacaladobarbosa@gmail.com.
} 
RESUMEN: Este ensayo busca combinar el concepto de subordinación, presentado por Fèdéric Gros en Desobedecer, y la teoría de la subordinación femenina, propuesta por filósofas feministas vinculadas a la Teoría de los Actos de Habla. El objetivo es mostrar que el paternalismo identificado por Gros como una marca de los acuerdos de subordinación está, en cuanto tal, presente en sociedades sexistas, desempeñando el papel de justificación moral para la subordinación de las mujeres a los hombres. El texto discute además el uso de insultos sexistas para mostrar como tales palabras reflejan una visión patriarcal del mundo y evocan estereotipos paternalistas. Además, se argumenta que el contra-discurso y la apropiación de insultos pueden funcionar como formas efectivas de resistencia y desobediencia al patriarcado.

PALABRAS CLAVE: Subordinación femenina. Sexismo. Insulto. Contra-discurso. Apropiación.

\section{INTRODUCTION}

In the last decades, feminist philosophers working with the Speech Acts Framework ${ }^{2}$, like Jennifer Hornsby and Rae Langton, have been particularly interested in how speech contributes to maintain women's inferior status in the structure of social power. Langton, particularly, developed a view according to which mainstream pornography can be understood as a form of speech act that subordinates women, since pornography depicts women as being aroused by violence and objectification ${ }^{3}$. These theorists characterize female subordination as the result of discursive practices that rank women as inferiors and legitimize discriminatory practices against them. In a clear sense, their respective philosophical positions provide some interesting ideas about what subordination does to women, but they do not focus on what subordination is.

Fortunately for those seeking to know more about what subordination is, Frèdéric Gros' 2016 book, Disobey: The philosophy of Resistance, contains an entire chapter devoted to the definition of subordination and the forms of obedience and resistance involved in the subordinative dynamics. Gros also proposes an analysis of the underlining paternalism that, as he argues, marks subordinative arrangements as such. He goes all the way back to Aristotle and Saint Augustine to reconstruct how philosophical views on politics and power promoted a paternalistic stance to justify the subordination of some to the authority of the few that represented social order.

The idea of joining together Gros' thoughts and the feminist understanding of women's subordination through speech then emerged as a promising project that could enrich both frameworks. In this paper, I will put forward such a project, specifying how Gros' book can dialogue with the feminist philosophy of language. I will recognize the paternalism he discusses in his chapter "From subordination to the right of resistance" as a component of the sexist ideology that continues to subordinate women to men even in the democratic societies of our days. In section 1, I present Gros' understanding of paternalism and obedience in subordinative arrangements. Then, in a brief subsection, I dwell on what allows us to characterize sexism in terms of ideological thinking. In section 2, I present the central notions of the Austinian Speech Acts theory and how they serve to understand the way flawed ideologies, such as sexism, find their way into the fabrics of society. Finally, I analyze how the toxicity of sexist speech, which can be observed in the existence of derogatory words that target women, like 'slut', 'bitch', 'sissy', can be blocked and resisted by strategies such counter-speech - the use of speech to explicitly oppose toxic practices - and the phenomenon of slur appropriation - that is, when derogatory words are used by members of the targeted group, as for example, uses of the n-word by African Americans.

\footnotetext{
${ }^{2}$ The speech acts theory, according to which speech is action, is a canonical theory in the philosophy of ordinary language nowadays. The central contribution of this theory is the thesis that language can do more than just represent states of affairs. That is, other than asserting propositional content, speakers can, for example, promise, order, enact laws etc. Finally, speakers can change states of affairs by means of the action they perform with language. Such actions will be determined by illocutionary features, such as the illocutionary force (which will be discussed in section 2) and other conventional procedures that determine if the speech act was felicitous or not. For more on the subject, see Austin (1962, 1970), Searle (1979), Vanderveken (1990).
}

${ }^{3}$ See Langton (1993). 


\section{THE OBEDIENCE OF SUBORDINATES IN PATRIARCHAL SOCIETIES}

Subordination is presented by Gros as a form of willful obedience to supposedly well-intended and virtuous superiors. He affirms, for example, that: "What is specific to subordination [...] is that the portion of will engaged in obedience is animated by the anchored conviction of the well-founded character of the orders that are given: reasonable and just, since they arise from a source that is supposed to be competent and virtuous, unspoiled and incorruptible” (GROS, 2020, p. 58).

To be a subordinate is then to engage in a seemingly well-justified though unbalanced system (which can be a microsystem or a macrosystem) of power-related roles, in which superiors are portrayed as dignified servants that protect their inferior's interests, installing order and fairness. The master here is not an oppressor, like the slave owner or the tyrant, but a dutiful leader and caretaker. Moreover, the master/slave dynamics in subordination is essentially paternalistic: the obedience from a subordinate does not derive its reason for being from legal or military control, but from his/her humble, subjected, and abnegated attitude.

As pointed out by Gros, in western political thought, this conception of obedience to authority can be traced back to the Greek philosophers. For instance, in his Politics ${ }^{4}$, Aristotle held that the relation between superiors and inferiors reflected the harmony of the cosmic order. He argued that, in face of an unequal yet natural distribution of talents, different individuals should occupy different positions in the sociopolitical hierarchy. For Aristotle, being a leader and taking place in public decision-making required political expertise as well as possessing a rational concern for the common good (Miller, 2017). In this account, a good leader (or good politician) was considered a fatherlike figure, who held his community's well-being as an absolute priority. This "loving" relationship between the leader and his community was, however, at heart asymmetrical: members of the community were not considered fit to hold unrestricted authority over the leader, and it is precisely the consciousness of their own limitations that makes subordinates resignedly accept their inferior status ${ }^{5}$.

To govern is to protect, to take care. Political subjects form a people of grateful and fearful children that the protecting and scolding state takes under its wing, its control, its tutelage. This obedience out of gratitude, which every ruler dreams of arousing, is directed at three qualities in the ruler: competence (we obey him because he has wisdom and expertise), virtue (we obey him because we know his moral integrity), and solicitude (we obey him because of his concern for others). (GROS, 2020, p. 53)

Gros further remarks that a comparable conception of subordinating authority is present in what he describes as the foundation of Augustine's political utopia, the concordia ordinata (cf. GROS, 2020, p.52). In Augustine, though, Christian virtues play an important part in describing the dynamics of subordination: the leader is loving, mirroring God's all goodness, and the subordinate is grateful, mirroring the deference of the creature before his/her creator.

As for disobedience, while the ancient Greek political thought treats it as a form of irrationality that violates a teleological justification, namely, the common good, Christian political thought, represented here by Saint Augustine, takes disobedience to be grave moral deviation. For the former, since one only becomes a subordinate to reach the ultimate end of personal and civic wellbeing (eudemonia and justice respectively), resisting obedience was considered, in the best-case scenario, a self-defeating attitude. For the latter tradition, subordinating oneself to an authority ordained by God himself reflected one's commitment to the superior goal of salvation. Violating the authority of God was a monstrous and senseless act of selfishness. In looking at these two conceptions of authority, thus, one can easily notice how subordination is connected to a species of paternalism.

\footnotetext{
${ }^{4}$ I will be considering the version of the work by Newman (2010).

${ }^{5}$ Plato seemed to favor a similar functionalist view of power relations when he claims that the perfect civil constitution is analogue to a healthy organism (soul), in which each part executes its corresponding function in harmony with the others (Republic, $588 \mathrm{~b} f \mathrm{f}$.).
} 
One good example of how paternalism works to make subordination seem fair and desirable can be found in patriarchal societies too, in which women are taught that their $\operatorname{sex}^{6}$ determines their inferior social status relatively to men ${ }^{7}$. But before I move on to discuss the subordination of women, a few clarifications are in order. First, I will be using 'patriarchy' here in its usual sense, that is, to refer to the unbalanced system of power distribution in which one's position in society - either as a superior or an inferior - is defined by one's sex: men holding more power than women (in binary societies). Secondly, I will take sexism to be the belief system that tries to justify the intrinsic inequality that characterizes patriarchal societies. So, the role of what I am calling paternalism here will be to justify subordination in sexist societies specifically from a moral perspective, offering putatively reasonable explanations as to why it is mandatory that men should rule, and women should obey. Finally, I will assume that what allows us to make a clear-cut parallel between the paternalism that Gros finds in the political theories of both Aristotle and Augustine and the paternalism I will treat here as the ideological backbone of women's subordination in the patriarchy is the general principle that some have the duty of ruling to protect, and others have the duty of obeying and being thankful for the protection that they are offered.

\subsection{SEXISM AND IDEOLOGY}

The concept of woman is essentially stereotypical, emerging, to a great extent, from the inculcation of sex-appropriate characteristics that make individuals capable of executing certain roles in their social lives. Binary sex-differentiation particularly is related to a conception of the social division of labor in which men and women are expected to develop distinct attitudes, motives, vocational interests, dressing codes, responsibilities within the home, etc. (MACKEY; CONEY, 2000). In that sense, what is typically taken as feminine or masculine accords with gender-specific normative expectations that typically bear a direct influence over the corresponding psychological, behavioral, and moral profiles that members of each gender exhibit. Yet, in patriarchal societies, as is well-known, sex/gender roles are not equal in what concerns rights and privileges. Consequently, sex roles are tied to unequal social power relations and to the ideologies that support them.

Although there are numerous definitions of ideology in the market today, a good way of defining it is as a temporarily persistent and socially extended cluster of mutually supporting - and often logically inconsistent - beliefs, interests and norms that accord with a world view (SWANSON, 2015). Typically, ideologies will have the justificatory function of presenting the world view that they support as correct and desirable (WYATT; WYATT, 2018) and that is precisely why ideologies that support unjust social systems can be considered flawed in at least two senses: morally and epistemically (STANLEY, 2015).

Common sense sexism is a clear case of flawed ideology in these two senses. Firstly, because it attempts to justify a bigoted world view according to which women are inferior to men, through a paternalistic depiction of women as less strong, more emotionally driven, and therefore in need of the rational guidance of men. The result is to legitimize the idea that men are not morally wrong in subordinating women.

From an epistemic standpoint, sexists will commonly explore scientific discourse in their attempts to naturalize sex differences, "[...] by making them seem inevitable, or portraying people trying to resist them as fighting a losing battle” (MANNE, 2017, p. 79). Twisting and distorting the concepts of nature and causality will be frequent sexist strategies to explain enduring dispositions for behavior that mark the social status of females. For example, sexists will appeal to natural causes, such as having XX chromosomes, to explain why there are less women in positions of power - in lieu of seeking for concurring circumstantial causes that have to do with social environment. This tendency is famously known as the correspondence bias (Gilbert \& Malone, 1995), a problematic kind of reasoning because resists rational scrutiny and revision, obstructing honest attempts to gain knowledge about the socially constructed causes behind women's place in patriarchal societies.

But paternalism is what makes sexism a subordinating ideology from a moral perspective. As a matter of fact, paternalism in general is the trademark of subordinative ideologies, like the ones identified by Gros in the political thoughts of both Aristotle and Saint

${ }^{6}$ I will not make a distinction between sex and gender. The terms will be used here as synonyms.

${ }^{7}$ Of course, the ways in which this inferiority manifests itself varies in degree, according to one's subculture. 
Augustine. It is the paternalistic assumption that subordinative arrangements are inevitable, rational, and Christian that founded the belief that resistance is a battle that determines self-annihilation as either rational beings or creatures of God. Analogously, it is paternalism that makes men think that there is nothing wrong in subordinating women.

Determining how sexism and paternalism find their ways into the fabric of society becomes, hence, an important task for any theoretical attempt to understand how the patriarchy operates to sustain toxic practices against women in action and speech. In the next section, I will begin to focus on this important matter; more specifically, on how linguistic behavior contributes to the continuation of paternalistic stereotypes linked to sexist ideology. I will discuss how Speech Acts Theory offers interesting tools to explain both the everyday linguistic practices that consolidate the stereotypes behind the subordination of women and how speech can be a way of resisting subordination.

\section{THE (BAD) THINGS WE DO WITH WORDS}

In her 1993 paper Speech acts and Unspeakable acts, Rae Langton proposes an extension of the Austinian Speech Acts Theory presented mainly in Austin (1962) - with the purpose of encompassing what she calls subordinative speech acts. She builds her argument on the assumption that: "The ability to perform speech acts of certain kinds can be a mark of political power. To put the point crudely: powerful people can generally do more, say more, and have their speech count for more than can the powerless. If you are powerful, there are more things you can do with your words". (LANGTON, 1993, p. 298-9).

Following Austin's characterization of the Speech Acts framework as a social activity theory (cf. LANGTON, 1993, p.302) and thus, in a sense, as a political theory, Langton tries to account for linguistic actions - things we do with words -, in terms of their underlining power relations. To better understand Langton's claims, I will begin with a brief presentation of Austinian concepts. As many philosophers of language point out today, one of Austin's most important legacies to the study of language was the idea that speakers do a lot more with words than just convey contents that purport to represent the world. He explained this general idea with the notion of illocutionary force.

The illocutionary force of a speech act determines what kind of action the utterer of a locution (a sentence) carries out by means of her utterance, that is, if she is asserting, making a promise, giving an order, etc. Consequently, the illocutionary force will be what explains the fact that the same locution can be used to perform different actions and produce different effects in the audience. Take the example of an utterance of (1), which can both be used to promise or to threaten someone.

I will allow black people to use the white only school bus.

Promising and threatening are two different actions that involve correspondingly different illocutionary features and provoke different kinds of effects in the audience, which Austin dubbed 'perlocutionary' effects. For example, in a scenario in which the utterance of $(1)$ is a threat, one of its perlocutionary effects will be to cause tension or fear in someone who does not wish that black people use the white only school bus (in that context of utterance). In the case of a promise, an utterance of (1) will have the perlocutionary effect of comforting and reassuring someone who wishes that African American students can use the same school bus as white students.

Now, some utterances, such as (2), can be what Austin called an exercitive speech act, that is, a speech act that when uttered by the right person, in the appropriate conditions, has the power to install a new state of affairs in the world.

From this day forward, women are no longer allowed to vote ${ }^{8}$.

\footnotetext{
${ }^{8}$ This type of speech act is exercitive and also verdictive, that is, it involves "the authoritative delivery of a finding about some matters of fact or value" (LANGTON, 1993, p.304). The hypothetical example is merely illustrative.
} 
If, for example, a president declares (2) in the appropriate circumstances, his/her illocutionary act will be the effective promulgation of a new law. Moreover, according to Langton, the Austinian model predicts that an utterance of (2) will: a) rank women as politically inferior to those who can still vote, b) legitimate discriminatory behavior towards women, and, finally, c) deprive women of civil rights. The output of an utterance of (2) will then be to subordinate women, turning them into vulnerable targets of disempowerment and even abuse. Consider more examples, such as the utterances of sentences (3)-(6) made by male politicians?

(4) She wanted a scoop. She wanted to scoop the scoop at any price against me.

(5) The country's problems have overwhelmed leaders who are men, how much more for a woman.

(6) Women must earn less than men because they are weaker, they are smaller, and they are less intelligent.

Notice how sentences (3)-(6) accord with sexism and implicitly use paternalism to justify the sexist world view they reverberate as correct. Men are portraited in each one of them as superiors who are more capable of controlling situations in virtue of their intelligence and rationality than women. This explains why they deserve the leading roles. Women, on the other hand, are viewed as weaker, manipulative, emotional and less intelligent beings, unworthy of occupying positions of power.

The world view that these sentences represent is justified by the belief that both sexes will be better off if men continue to rule. Fighting this proposed division of social labor is irrational and vain, serving only to disturb social well-being for no good reason. This sexist configuration places men as a dominant group and women, as a targeted one. And, as Langton insists, like all other social practices, theses linguistic practices will not be immune to their respective underlining power structures.

One way in which language is clearly affected by forms of unbalanced power distribution can be observed in the analysis of derogatory words. Such words represent symptoms of unjust systems, in which those who are powerful have tacit - and sometimes even legal - permission to cause harm to powerless groups. As we will see in what follows, the constant repetition of uses of derogatory words to refer to female behavior is both an indication and a mechanism of continuity of the sexist subordination that characterizes the patriarchy.

\subsection{HOW DEPRECIATION ENABLES SUBORDINATION}

Depreciative speech sometimes functions as a form of daily-life social control, being used to sanction behavior negatively by inflicting emotional harm. In the case of sexist depreciative language in binary societies like ours, the harm that is inflicted in targeted individuals comes, in the first place, from the fact that sex differentiation stipulates specific rules of behavior for each sex; as, for instance, that women ought to be modest and that men ought to be strong and rational, avoiding sentimentality. Any individual who exhibits behavior that distances itself from the expectations generated by such stipulations will typically become the potential target of depreciative practices. To understand how this works, take the following sentences with the derogatory words, 'slut' and 'sissy':

That girl dresses like a slut.

He is crying over nothing! What a sissy! ${ }^{10}$

Both 'slut' and 'sissy' are commonly included amongst slurs, words conventionally associated to depreciation, taboo language and, of course, offense. The so-called group slurs, namely, slurs directed at underprivileged social groups, have received broad attention from linguists and philosophers in the past decades because of their connection to discriminatory practices that target categories like race, sexual orientation, ethnicity etc. Some well-known examples of group slurs are: 'nigger' (from American English, directed

\footnotetext{
${ }^{9}$ These sentences are real examples of declarations made by male politicians from different countries around the world (MARGOLIS, 2017)

${ }^{10}$ Women who dress provocatively are considered as relevantly distancing themselves from the paternalistic female stereotype of a domestic and modest woman. Likewise, men who show emotions in inadequate ways are taken as inferiors as men.
} 
at the African American community), 'paraíba' (from Brazilian Portuguese, directed at those who come from the northeast region of Brazil) and sexual orientation slurs, like 'sapatão' (directed at lesbians), 'viado' (directed at homosexual men) and, 'traveco' (directed at transsexual women) ${ }^{11}$, also from Brazilian Portuguese.

The words 'slut' and 'sissy', from American English, represent the so-called gendered slurs, that is, slurs that derogate in virtue of gender (or sex)-related behavior ${ }^{12}$. For example, uses of 'slut' will typically rank individuals as morally inferior in virtue of their sexual behavior and mark their conduct as one to be avoided. 'Sissy' also ranks some men as inferior to others, by marking an assumed inadequate male conduct in terms of its proximity to feminine behavior. Notice that even though 'sissy' is an insult directed at men, its derogatory content comes not from a properly masculine characteristic but rather from a misconception about sentimentality as an inferior characteristic admissible in women but unacceptable in men. Women are once again here the ultimate target of the derogation.

Theorists interested in the phenomena of hate speech usually talk about derogatory language, exemplified by (7) and (8) above, in terms of a metaphor with toxicity, referring to depreciative words as toxins that have the power to affect mental and social health. This idea appears in the workings of Lynne Tirrell, who is well-known for her study of how constant uses of slurs in Rwanda, right before the Rwanda genocide of 1994, helped prompt the dehumanization of the Tutsi ethnicity (cf. TIRRELL, 2017, p.144).

For Tirrell, depreciative speech is a mark of discursive toxicity:

Deeply derogatory words, a special category of even more powerful slurs, are part of the systems of oppression in which they are embedded; their toxicity creates and reinforces to both targets and communities [...] Further, it [the conception of discursive toxicity] highlights the role of uptake and susceptibility [...] A sketch of the concept of toxicity highlights the mechanisms by which speech acts and discursive practices can inflict harm. (TIRRELL, 2017, p. 141)

As the fragment above indicates, the author offers a description of the mechanisms by means of which unbalanced power systems, like the patriarchy, feed on depreciation, helping to sustain unfairness. For Tirrell, repetitions of deeply derogatory words - like 'slut' and 'sissy' - on a day-to-day basis constitute one of the most effective mechanisms for sustaining unequal systems. In her metaphor, these uses function as toxic substances circulating through the blood system of a poisoned organism. If they meet no resistance in their trajectory, through the action of an antidote or medicine, the toxin will spread and provoke illness and death. Analogously, in the case of a social organism, the repeated use of derogatory words may eventually lead to social division and even strife.

Authoritative speech acts, specifically, will play a central part in disseminating this toxicity. When derogatory words are used by individuals that occupy positions of power, such as politicians, fathers, mothers, teachers, priests, and experts in general, their uses will tend to be harder to contest, since these individuals have practical and epistemic authority: those under their leadership or tutelage will feel authorized by their examples to repeat their uses, strengthening the stereotypes they bear.

Sexists occupying positions of authority will, in many cases, use a species of realism, that is paternalistic in essence, as a camouflage to hide this noxious characteristic of words like 'slut' and 'sissy'. They will argue that 'slut' and 'sissy' are not unfair sexist words because deviant behavior related to sex-roles requires policing practices to guarantee social stability. This realistic approach takes concepts like 'being a slut' and 'being a sissy' as descriptive rather than essentially normative, as if we lived in a world where sluts and

\footnotetext{
${ }^{11}$ The word 'travesti has been through a process of meaning change and is now commonly used as a synonym for 'transgender women'. For more on the term, see Carvalho (2018) e Oliveira e Grossi (2014).

${ }^{12}$ It is important to briefly remark, however, that there is some dispute regarding the status of words that derogate in virtue of gender as slurs, since some argue that they lack a descriptive and neutral counterpart, that is, a concept that has as its extension the members of the targeted group but lack the derogatory content carried by the slur. For example, while a paradigmatic slur like 'nigger' has a descriptive neutral counterpart, namely, 'African American', 'slut' and 'sissy' can only be paraphrased in reference to normative counterparts. I shall not dwell on that here, so I will identify these expressions not as slurs, but solely as derogatory words and talk about slur appropriation, in section 3, solely as appropriation. See Ashwell (2016) for more on the subject.
} 
sissies really did exist and were deserving of discrimination and harm. If one is convinced that these practices of social policing are fair, then there is no moral justification for the desire to relinquish them.

Nevertheless, for those still not convinced by such strategies, the question "is resistance pointless?" continues to be worth making. After all, wouldn't the effort to denaturalize the patriarchy as well as the active confrontation of the stereotypes it evokes work as powerful antidotes against subordination and discrimination? Theorists like Langton and Tirrell will defend that they are. Langton particularly will argue that one would only have to appeal to the Austinian notion of uptake of a speech act to understand and undertake resistance.

Langton's colleague and co-author, Jennifer Hornsby offers a good explanation of what an uptake is: "[...] what Austin called 'uptake' is an effect of a very special kind, which is peculiar to some linguistic acts. What is special about illocutionary effects is that our concepts for them (saying to another, for example) are just the speech act concepts of the actions whose effects they are." (HORNSBY, 2000, p.4).

In other words, according to Hornsby, the uptake of a speech act corresponds quite simply to the recognition of a certain piece of speech as the action it purports to be.

Hence, not recognizing a given sample of speech as the action it purports to be can work as a way of resisting depreciative speech. Imagine, for example, that a father of two is with his older son in the front yard of his house and utters (8) - "He is crying over nothing! What a sissy!" - while watching his younger son react with a tantrum after losing his favorite toy. Here, the father is a figure of authority and the uptake of his speech act will determine the ranking of his younger son as an inferior. In a typical scenario, the older son will take his father's authority to indicate that there is nothing wrong with using depreciative speech when classifying individuals in terms of their sex-related behavior. Furthermore, because it is harder to raise objections to figures of authority, the older son will typically accommodate this information to the common ground of assumptions that he shares with his father, feeling authorized to suppose that the same assumption can be presupposed in future conversations ${ }^{13}$.

Suppose now an alternative context in which the older son has just taken classes on gender equality at school and is now aware that (8) is an unacceptable way of describing his younger brother. He believes that the word 'sissy' is violent, noxious, and unfair for portraying sentimentality and women in a non-favorable light. In this new scenario, the older son may reject his father's conversational contribution by means of counter-speech, namely, speech that tries to oppose a previous speech act, blocking its accommodation to the common ground ${ }^{14}$. He can say something like:

Don't say that, dad! Boys cry too. There is no need to use that word.

A reply such as (9) does two things: a) it obstructs the uptake of the authoritative act as such ${ }^{15}$, and b) it blocks the accommodation of $(8)$ as a valid conversational contribution.

This hypothetical example purports to show thus that reacting to conversational contributions that depreciate vulnerable groups with a refusal to accommodate their content to the common ground can be a way of resisting what Tirrell calls the epidemic of toxic speech. These minor acts of insubordinate behavior will operate by helping to locally block the unfair ranking, the legitimization of discrimination and the prospect of deprivation of rights ${ }^{16}$.

\footnotetext{
${ }^{13}$ The common ground of assumptions that is shared by two or more speakers is usually defined in terms of presupposed information. For example, the father and son in the example share presuppositions about their surroundings, their family, their language etc. For more, see, for example, Stalnaker (1999, 2002).

${ }^{14}$ One accommodates a piece of information to a common ground of presuppositions by simply introducing it as presupposed information - as in the first case scenario. For example, in the second case scenario, the older son treats the information as problematic, refusing precisely to presuppose it.

${ }^{15}$ Even though the older son's reply does not directly question his father's authority, it does question his father's world view, denouncing its sexist discursive toxicity.

${ }^{16}$ The fact that the blocking achieved in this case is local makes repetition necessary. It also evidences, for example, the need for public figures of authority to practice counter-speech systematically, so that its effects can be more significant.
} 
Yet, rejecting conversational contributions with counter-speech is not the only way to block toxicity. Protesting, in its many forms, is itself an important weapon of resistance, as are phenomena such as appropriation. It is no wonder then that slur appropriation, in particular, has received a great deal of attention from public opinion as well as from the academic community lately. In the next section, I will focus on why we can consider it a form of insubordination.

\section{APPROPRIATION AND THE RIGHT TO RESIST}

In our example of the conversation between father and son above, we took the utterance of (9) to be an example of resistance to a subordinative speech act - one that targets women - through the rejection of a conversational contribution. We also ended the last section with a comment on the possibility of discussing other forms of resistance to "words that wound" that did not necessarily involve the rejection to accommodate information.

As noticed by Langton, such alternative ways of disobeying can and do take the form of actions of protest that sometimes do not involve saying any word: "When Rosa Parks responded by sitting where only whites were permitted, she didn't refute a false assertion. She disobeyed a true rule" (LANGTON, 2018, p. 144). As a matter of fact, the appropriation of derogatory words is a kind of disobedience that resembles Parks' protest, as I will try to show.

Appropriation is one of the stages of word-resignification or meaning change. It consists in using a term conventionally associated to the derogation of one's group to refer to one's own group. In the cases in which the targeted community endorses this inversion in future usage, the meaning of the word will change, transforming itself, and acquiring a neutral and, thus, new meaning (NUNBERG, 2018). It is what happened, for example, with the words 'gay' and 'queer', which began as derogatory but ended up being re-signified by the LGBTQIA+ community and became descriptive expressions with meanings that are now very distant from their original connotations.

Appropriation will have as its most beneficial outcome, of course, the total relinquishment of the power to wound that the derogatory word originally had. Meaning change represents, as such, a victory against toxic speech, a powerful antidote to the continuation of discriminatory discursive habits. Nevertheless, I am interested here not in the outcome of the process, but in the characteristics of its first stages. The reason why appropriation is especially interesting for my purposes is that it serves to evidence the existence of the paternalistic stereotypes I have been discussing so far. Consider an example: suppose that (10) is uttered by a woman:

You know that I am not afraid to give orders to my employees when I must, right? I am what they call a bitch with capital 'b'.

Like 'slut' and 'sissy', 'bitch' is also considered a gendered insult. It is most used to refer to assertive women that do not fit the paternalistic stereotype of the self-possessed, deferential woman. Now, when a woman willingly identifies herself as a 'bitch', in a case such as (10), she does not intend her appropriated use of the word to be deprived of its derogatory content, quite the opposite: the irony of her use of 'bitch' depends precisely on the word being derogatory. Her use of 'bitch' aims at indicating that there is nothing wrong with being assertive when one is a woman, and its irony arises from the fact that the appropriation of the word ridicules the discrimination of women.

Notice that although the utterances of both (10) and (9) are forms of resistance to the continuation of female subordination, only (10) represents a strategy that does not involve using more speech with the purpose of convincing the bigot. It is, in that sense, like the cases of appropriation that are now popular in contexts of political protest, such as the appropriated uses of the word 'vadia' (Brazilian Portuguese for 'slut') by the Marcha das vadias' movement in Brazil ${ }^{17}$ or the appropriation of 'bruja' (Spanish for 'which')

\footnotetext{
${ }^{17}$ It is the name given to the Brazilian version of the feminist protest 'Slut Walk', that took place in Toronto, Canada, in 2011, for the first time. The aim of these historical series of protests was to denounce rape culture.
} 
in the now popular feminist saying 'somos las nietas de las brujas que no pudisteis quemar' ${ }^{18}$. In these two cases, the appropriation purports to cast down the negativity associated to sexual freedom, independence and aging in women, respectively. Moreover, they denounce the patriarchy as the source of structural disadvantages that place women as the main targets of rape culture and systematic psychological violence by putting word meaning in evidence.

Appropriated uses of derogatory words may however fail. Suppose (10) is uttered by a man. In that case, his use of 'bitch' will not count as appropriated for the simple reason that the utterer is outside of the targeted group. Such uses are not only still potentially offensive but, in contrast to the case of (10), they fail to present the derogatory word in the ironic or defiant way that counts as insubordination against an unjust system of power. To properly appropriate a derogatory word, one must be aware of one's own group membership.

Another interesting aspect of appropriation is its relation to freedom of speech. There is a considerable number of papers as well as an ample debate over the alleged right to use derogatory words as a matter of freedom of speech ${ }^{19}$. Though appropriation aspires to block the harmful effects of hate speech in the long run, as we saw, it does not operate by eliminating the word itself; instead, it uses freedom of speech to achieve its goal of denouncing the ideologies that sustain bigotry and changing the conventions ruling the use of the word in question. Therefore, appropriation does not purport to silence the bigot either directly through convincement or prohibition, but by beating him in his own "game of freedom".

Also, in a context of disempowerment, it may be the best form of resistance available. If one does not have the authority to prohibit forms of speech or to convince through speech, one can fight a toxic speaker by neutralizing or immobilizing the power to wound and subordinate that his/her words have.

Finally, as Langton (2018) highlights, appropriation operates mainly at the level of perlocutionary effects or "future effects". In the case of gendered derogatory words, for example, appropriation affects the perlocutionary legitimization of discriminatory practices and the potential deprivation of civic rights. In commenting Butler's understanding of resignification, Langton says:

This has something in common with a hope expressed by Judith Butler, that hearers might later 'resignify' oppressive speech [...] She sees this, it seems, as a perlocutionary resistance, arising from the 'gap' between a speech act and its future effects. These effects include later change to locution, for example, in reclamation projects that, over time, change what can be done with words like 'queer', that in earlier usage were injurious in their effects. (LANGTON, 2018, p. 157)

This is one more asymmetry between the example of (9) and the example of the political uses of ' $v a d i a$ ' and 'bruja'. While in the case of (9), the son's refusal to accommodate the derogatory content of 'sissy' and the reasons he offered for the rejection worked as counter-speech, the ironic appropriated use of 'bitch' in (10), but specially the appropriation of 'vadia' and 'bruja' in political contexts of protest, aim at producing a future in which such words will no longer be used to discriminate or legitimize discrimination.

We can then affirm that appropriation is as such a form of epidemic control that any agent can take part in when opposing discriminatory speech. By using irony and clearly defying the stereotypical thinking of which flawed ideologies are built, it is a special kind of cheeky response that immobilizes subordination.

At the end, perhaps, we can even find similarities between the disobedience in speech that appropriated uses exemplify and the disobedience of Christian mystics that Gros discusses by the end of his chapter on subordination. On the one hand, he describes the obedience of mystics, such as St. John of the Cross and St. Teresa of Avila, as follows: "What mystics require are real orders, which means harsh and terrifying orders that insult their dignity, wound their honour, exhaust their good will, train them to the limits of

\footnotetext{
${ }^{18}$ The sentence is originally the title of a book by Ame Soler that refers to the phenomenon of witch hunt in the modern era, which persecuted and killed mainly women.

${ }^{19}$ See Hornsby \& Langton (1998), Croom (2014) and Barnes (2011).
} 
their capacity to deny themselves, forget themselves in servitude, abandon themselves in humiliation and shame". (GROS, 2020, p. 58).

He continues, "The master is even provoked and challenged [...] with the result that even submission seems founded on an act of free will" (ibidem, pp. 58-60). At least in terms of the effects caused on the master of the subordinative arrangement, the disobedience involved in appropriation, like the one of the mystics, provokes shock given its apparent inclination towards the endorsement humiliation and shame. As in the case of the mystic, the disobedience comes from the bewildering free acceptance of the imposed submission, even if we keep in mind that the mystic disobeys the master because of his/her incessant need for abnegation ${ }^{20}$ and the "appropriator" seeks to highlight the existence of submission, discrimination, and exclusion in order to eclipse them.

\section{CONCLUDING REMARKS}

In looking at the things we can do with words we become aware of the fact that our actions are embedded in power relations that are in many ways unbalanced, and a quick look at the contemporary western world can confirm that. Once we look through the veil of ideology, we are presented with a crude reality in which groups of people are subordinated by others with no other justification than their race, sex, class, religion etc. And we often find ourselves in situations that reproduce this flawed way of thinking and living.

From the many forms of inequality that we face on a day-to-day basis, sexism is one that defines the western world as it is and, as we saw, it consists of a justificatory ideology whose backbone is a subordinative paternalism, according to which men should remain at their historical position of privilege solely in virtue of their assumed superior capacity to uphold authority. Gros' book makes an insightful reconstruction of this paternalism in discussing subordination and the forms of obedience and disobedience involved in it.

The paternalism discussed by Gros has obvious parallels with current feminist discussions on how speech operates to subordinate women. Here, I focused on this point: trying to identify how paternalism manifests itself in practices involving derogatory and potentially offensive speech and how they impact the status of women in the social sphere.

Here, I discussed how toxic speech is used to get individuals to abandon any deviation from what their socially stablished sex-roles determine. Notwithstanding, I also showed that the paternalism can be resisted. In the last section, I focused on examples of counterspeech through blocking of accommodation and word appropriation, showing how they serve to defy subordination by doing the right thing with words.

\section{REFERENCES}

AUSTIN, J.L. How to do Things with Words. $2^{\text {nd }}$ ed. J.O. Urmson and M. Sbisá (eds.), Cambridge, MA: Harvard University Press, 1962.

AUSTIN, J.L. Philosophical Papers. URMSON, J. \& WARNOCK, G. (ed.). Oxford: Oxford University Press, 1970.

BARNES, A. E. Slurred speech: free speech rights and social media on the college campus, 2014. Retrieved from the University of Minnesota Digital Conservancy, https://hdl.handle.net/11299/167285.

CARVALHO, Mario. “"Travesti”, “mulher transexual”, "homem trans” e "não binário”: interseccionalidades de classe e geração na produção de identidades políticas”. Cadernos Pagu, n. 52, 2018.

\footnotetext{
${ }^{20}$ The discursive disobedience of abnegation operates as a disguise: the free acceptance of humiliation is not an act of limitless negation of the self.
} 
CROOM, A. M. Slurs. Language Sciences, v. 33, n. 3, p. 343-358, 2011.

GILBERT, D. T.; MALONE, P. S. The correspondence bia”. Psychological bulletin, v. 117, n 1, p. 21-38, 1995.

GROS, F. Disobey! A Philosophy of Resistance New York: Ed.Verso. 2020.

HORNSBY, J. Feminism in philosophy of language: communicative speech acts. Cambridge: Cambridge University Press, 2000.

HORNSBY, J.; LANGTON, R. Free speech and illocution. Legal Theory, v. 4, n.1, pp. 21-37, 1998.

LANGTON, R. Speech acts and unspeakable acts. Philosophy \& Public Affairs, v. 22, p. 293-330, 1993.

LANGTON, R. Blocking as counter-speech. In: FOGAL, D., HARRIES, D.W.; MOSS, M. (ed.). New work on speech acts, 2018. p.144156.

MACKEY, W. C.; CONEY, N. S. Gender roles, traditions, and generations to come: the collision of competing interests and the feminist paradox. New York: Nova Publishers, 2000.

MARGOLIS, H. "17 times Politicians have resorted to wildly sexist speech over the last year”. Em The New York Time, 13 mar. 2017. Disponível em: https://www.hrw.org/news/2017/03/13/17-times-politicians-have-resorted-wildly-sexist-speech-over-last-year. Acesso em: 24 de agosto de 2021. 든

MANNE, K. Down girl: The logic of misogyny. Oxford: Oxford University Press, 2017.

MILLER, F. “Aristotle's Political Theory'. In: ZALTA, E. (ed.). The Stanford Encyclopedia of Philosophy. Palo Alto: CSLI 2017. Available in: https://plato.stanford.edu/entries/aristotle-politics/. Access in: oct. 10, 2020.

NEWMAN, W. L. (ed.). Politics of Aristotle: with an introduction, two prefatory essays and notes critical and explanatory. Cambridge University Press, 2010.

OLIVEIRA, M. B. de; GROSSI, M. P. “A invenção das categorias travesti e transexual no discurso científico”. Revista Estudos Feministas, v. 22, n. 2, pp. 699-701, 2014.

PLATO. The Republic.Hong Kong: Naxos, 2001.

POPA-WYATT, M.; WYATT, J.L. Slurs, roles and power. Philosophical Studies, v. 175, n.11, p. 2879-2906, 2017.

SEARLE, J. Austin on locutionary and illocutionary acts. The Philosophical Review, v. 77, p. 405-424, 1968.

STALNAKER, R. Context and content: Essays on intentionality in speech and thought. Oxford: OCSS, 1999.

STALNAKER, R. Common Ground. Linguistics and Philosophy, v. 25, n.5-6, p. 701-721, 2002.

STANLEY, J. How propaganda works. Princeton: University Press, 2015. 
SWANSON, E. Slurs and ideologies. Analyzing Ideology: Rethinking the Concept, 2015. Available in: http://wwwpersonal.umich.edu/ ericsw/research/Swanson,\%20Slurs\%20and\%20Ideologies\%20November\%202015.pdf. Access in: Nov. 7 , 2020.

TIRRELL, L. Toxic speech: Toward an epidemiology of discursive harm. Philosophical topics, v. 45, n 2, p. 139-162, 2017.

VANDERVEKEN, D. Meaning and speech acts, vols I and II. Cambridge: Cambridge University Press, 1990.

\section{(c) (ㅇ) $\odot$}

Recebido em 09/02/2021. Aceito em 03/03/2021. 